\title{
Prospective Analysis of Hemorrhagic Cystitis and BK Viremia in Allogeneic Hematopoietic Stem Cell Transplantation
}

\author{
Allojeneik Hematopoietik Kök Hücre Nakli Hastalarında Hemorajik Sistit ve BK Viremisinin \\ Prospektif Analizi
}

(D) Erden Atilla1, (D) Can Ateş2, (D) Atilla Uslu1, (D) Pınar Ataca Atilla1, (D) Istar Dolapçı3, (D) Alper Tekeli3, (D) Pervin Topçuoğlu1

${ }^{1}$ Ankara University Faculty of Medicine, Department of Hematology, Ankara, Turkey

2 Van Yüzüncü Yıl University Faculty of Medicine, Department of Biostatistics, Van, Turkey

${ }^{3}$ Ankara University Faculty of Medicine, Department of Microbiology, Ankara, Turkey

\section{Abstract}

Objective: BK virus (BKV) infection has been shown to be related to hemorrhagic cystitis ( $\mathrm{HC})$ in allogeneic hematopoietic stem cell transplantation (allo-HSCT). There are conflicting data regarding the association between BKV titers in plasma and clinical disease as well as the risk factors for BKV-related HC. Our aim is to study the risk factors and relationship with plasma BK viral load for development of $\mathrm{HC}$ in a prospective analysis.

Materials and Methods: We prospectively evaluated 59 patients who received allo-HSCT between 2014 and 2016 by quantitative BK virus polymerase chain reaction (PCR) (Altona Diagnostics, Germany) from blood samples at days $0,30,60$, and 90 after allo-HSCT. The patients were monitored for signs and symptoms of $\mathrm{HC}$.

Results: HC was diagnosed in 22 patients (37\%) at a mean of 100 days (range: 0-367 days). In multivariate analysis, the usage of cyclophosphamide (sub-distribution hazard ratio [sdHR]: 7.82, confidence interval $[\mathrm{Cl}]$ : $1.375-39.645, p=0.02$ ), reactivated CMV (sdHR: 6.105, Cl: 1.614-23.094, $\mathrm{p}=0.008$ ), and positive BKV viremia (sdHR: 2.15, Cl: 1.456-22.065, $\mathrm{p}=0.01$ ) significantly increased the risk of developing $\mathrm{HC}$. Patients with higher viral loads at day 30 and day 60 were diagnosed with more severe $\mathrm{HC}(\mathrm{p}<0.001)$. Median BK viral loads of $>101.5$ copies $/ \mathrm{mL}$ at day 0 (sensitivity 0.727 , specificity 0.875 ), $>98.5$ copies $/ \mathrm{mL}$ at day 30 (sensitivity 0.909 , specificity 0.875 ), and $>90.0$ copies $/ \mathrm{mL}$ at day 60 (sensitivity 0.909 , specificity 0.875 ) were indicative of $\mathrm{HC}$.

Conclusion: Our study showed that administration of cyclophosphamide, CMV reactivation, and BK virus positivity were associated with HC. Plasma BK virus PCR titers at days 0, 30, and 60 after transplant were sensitive tools for predicting clinically proven $\mathrm{HC}$.

Keywords: Hemorrhagic cystitis, BK viremia, Cytomegalovirus, Graft versus host disease

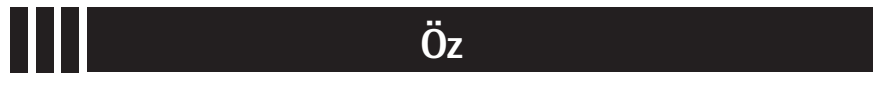

Amaç: BK virüs (BKV) enfeksiyonun allojeneik hematopoietik kök hücre naklinde (allo-HKHN) hemorajik sistit (HC) ile ilişkili olduğu gösterilmiştir. Literatürdeki çalışmalarda plazmadaki BKV titresi ile klinik hastalık arasında ve BKV ilişkili HC risk faktörleri açısından çelişkili veriler mevcuttur. Amacımız, prospektif olarak HC gelişimi risk faktörleri ile plazma BK viral yükü arasındaki ilişkinin gösterilmesidir.

Gereç ve Yöntemler: 2014-2016 yılları arasında 59 allo-HKHN alıcısının 0, 30, 60 ve 90. günlerdeki kan örneklerinden kantitatif olarak BK virüs polimeraz zincir reaksiyonu (PCR) (Altona Diagnostics, Almanya) değerlendirilmiştir. Hastalar HC belirtileri ve semptomaları açısından izlenmiştir.

Bulgular: Yirmi iki hastada (\%37) nakil sonrası ortalama 100. günde (0367 gün) HC tanısı konmuştur. Çok değişkenli analizde (siklosfosfamid alan [SdHR]: 7,82, güven aralığı [GA]: 1,375-39,645, $p=0,02)$, CMV reaktivasyonu geçiren (SdHR: 6,105, GA: 1,614-23,094, $p=0,008$ ) ve $B K$ virüs pozitifliği (SdHR: 2,15, GA: 1,456-22,065, p=0,01) olan hastalarda artmış HC riski saptanmıştır. Viral yükleri 30. ve 60. günlerde yüksek tespit edilen hastalarda daha ciddi HC görülmüştür $(p<0,001)$. Ortanca BK virüs yükü 0 . günde $>101,5$ kopya $/ \mathrm{mL}$ (sensitivite 0,727 , spesifite 0,875 ), 30. günde $>98,5$ kopya/mL (sensitivite 0,909, spesifite 0,875 ), 90. günde $>90,0$ kopya/mL (sensitivite 0,909 , spesifite 0,875 ) ise bu durumlar HC göstergesi olabilir.

Sonuç: Çalışmamızda siklofosfamid, CMV reaktivasyonu ve BK virüs pozitifliği HC ile ilişkili olduğu gösterilmiştir. Plazma BK virüs PCR titleri transplant sonrası 0,30,60. günlerde klinik olarak kanıtlanmış $\mathrm{HC}$ için hassas araçlardır.

Anahtar Sözcükler: Hemorajik sistit, BK viremi, Sitomegalovirüs, Graft versus host hastalığı 


\section{Introduction}

Hemorrhagic cystitis $(\mathrm{HC})$ is a cause of morbidity and mortality that occurs in 10\%-25\% of hematopoietic stem cell transplantation (HSCT) recipients $[1,2]$; some studies have reported an incidence of up to $70 \%[3,4]$. Symptoms vary from microscopic hematuria to severe obstructive nephropathy [5]. Early hematuria is usually the result of chemotherapy toxicity; however, late-occurring $\mathrm{HC}$ is multifactorial. The risk factors for $\mathrm{HC}$ include the type of conditioning, timing of engraftment, usage of cyclophosphamide (Cy), development of graft versus host disease (GVHD), presence of BK virus (BKV) infection and other viral infections, advanced age at transplantation, and thrombocytopenia or coagulopathy $[6,7,8,9,10,11]$.

Polyomavirus hominis 1, also called BK virus, is a nonenveloped, encapsulated DNA virus in the family Papovaviridae [1]. The shedding of latent BKV is frequently detected in immunocompromised individuals $[12,13]$. The association of BKV-related HC in HSCT settings was first reported by Arthur et al. $[14,15]$. Asymptomatic BKV shedding without clinical relevance might be detected by polymerase chain reaction (PCR) in urine $[16,17]$; $B K$ infection generally develops in more than $50 \%$ of allo-HSCT patients in peri-engraftment weeks, but overt HC occurs in about 20\% of patients [17]. There is a conflicting relationship between BKV titers in plasma and clinical disease, which may come from discrepancies between studies $[18,19]$. A high-level of BK viremia $\left(>3-4 \log _{10}\right.$ copies $/ \mathrm{mL}$ ) has been shown to be correlated to BKV-HC [20]. Our aims in this prospective study are to detect the risk factors for HC following allo-HSCT and to illustrate the relationship between plasma BK viral load and $\mathrm{HC}$.

\section{Materials and Methods}

We included 59 adult patients who underwent allo-HSCT between 2014 and 2016 for any hematological disease at our institute. Institutional ethical board approval and the informed consent of all participants were obtained. This project was supported by grant number 15B0230007.

Patients were monitored for signs and symptoms of $\mathrm{HC}$ at initial admission for allo-HSCT and routinely in outpatient visits. Lateonset $\mathrm{HC}$ was generally defined as $\mathrm{HC}$ occurring more than one week after transplant [21]. Hematuria was defined as $>5$ red blood cells in high-powered field microscopy, or documented gross hematuria with or without symptoms of cystitis. The grade of hematuria was defined according to criteria described by Bedi et al. [2]. A diagnosis of HC was made when clinically significant macroscopic hematuria (grade 2 or higher) was present. All patients received standard supportive care, including antifungal, antiviral, and antibacterial therapy (ciprofloxacin) for prophylaxis prior to allo-HSCT.
Patient plasma samples were collected prospectively prior to allo-HSCT and on days 30,60, and 90 after transplant, as well as in each $\mathrm{HC}$ attack, and stored at $-96{ }^{\circ} \mathrm{C}$. BK virus testing was performed in the microbiology laboratory. Viral DNA was extracted with a OIAmp DNA Mini Kit, and viral load was detected with a Real Star BKV and JCV PCR Kit (Altona Diagnostics, Germany) with the real-time polymerase chain reaction method in a Rotor-Gene 0/6000 (OIAGEN, Germany). The concentration of BKV DNA molecules that can be assigned with a positivity rate of $\geq 95 \%$ and determined by probit analysis

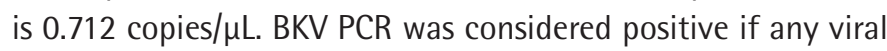
copies were identified. Patients were diagnosed with BKVassociated $\mathrm{HC}$ when they had grade 2 or higher hematuria in addition to positive BKV PCR.

To compare patients with or without occurrence of $\mathrm{HC}$, chisquare and Fisher exact tests were used where appropriate. Risk factors for the development of BKV-HC were evaluated first in univariate and then in multivariate analyses. The Spearman correlation (rho) test was used to evaluate the relationship between $\mathrm{HC}$ grades and BK viral loads. ROC analysis was performed to determine the positive thresholds of BK viral loads. The most specific and sensitive points under the line were detected by the Youden index. A p-value of less than 0.05 was considered statistically significant. The statistical analyses were performed using SPSS 20.0 (IBM Corp., Armonk, NY, USA).

\section{Results}

The median age of the participants was 41 (range: 22-71) years; 18 patients $(31 \%)$ were aged $>50$. The male/female ratio was $1.36(34 / 25)$. Malignant hematological disease (acute myeloid leukemia [AML], acute lymphoblastic leukemia [ALL], or myelodysplastic syndrome [MDS]) was diagnosed in 52 patients (88\%). The stem cell source was peripheral blood in 52 patients $(88 \%)$ and bone marrow in 7 patients $(12 \%)$. The stem cells came from HLA-matched related donors for 23 patients (39\%), haploidentical donors for 5 patients (8\%), and unrelated donors for 31 patients (53\%). A myeloablative conditioning regimen was administered for 37 patients (63\%), and 44 patients $(75 \%)$ received cyclophosphamide (Cy). The most common GVHD prophylaxis administered was cyclosporine (CSA) plus methotrexate (Mtx) in 49 patients (83\%), followed by mycophenolate mofetil (MMF) plus Mtx in 5 patients (8\%). Five patients (8\%) underwent haploidentical allo-HSCT and received tacrolimus, MMF, and Cy for GVHD prophylaxis. Acute GVHD was diagnosed in 38 patients (64\%) at a median time of 67 days: grade I-II gastrointestinal/skin/liver in 31 patients (84\%) and grade III-IV gastrointestinal/skin/liver in 6 patients (16\%). The median times to neutrophil and platelet engraftment were 20 days (range: 11-45) and 21 days (range: 9-48), respectively. Patient characteristics are summarized in Table 1. 


\begin{tabular}{|l|l|}
\hline \multicolumn{2}{|l|}{ Table 1. Patient characteristics. } \\
\hline Characteristics & $\mathbf{n}(\%)$ \\
\hline Age $>50$ years & $18(31 \%)$ \\
\hline Sex & $34(58 \%)$ \\
Male & $25(42 \%)$ \\
Female & \\
\hline Diagnosis & $7(12 \%)$ \\
Benign (SAA, FAA) & $52(88 \%)$ \\
Malignant & \\
(AML, ALL, MDS) & $7(12 \%)$ \\
\hline Stem cell source & $52(88 \%)$ \\
Bone marrow & \\
Peripheral blood & \\
\hline Donor type & $23(39 \%)$ \\
Related & $5(8 \%)$ \\
HLA-matched relate & $31(53 \%)$ \\
Haploidentical & \\
Unrelated & $37(63 \%)$ \\
\hline Conditioning regimen & $22(37 \%)$ \\
Myeloablative & $38(64 \%)$ \\
Reduced-intensity & \\
\hline Presence of acute GVHD & \\
\hline SAA: Severe aplastic anemia, FAA: Fanconi aplastic anemia, AML: acute myeloid \\
leukemia, ALL: acute lymphoblastic leukemia, MDS: myelodysplastic syndrome, GVHD: \\
graft versus host disease.
\end{tabular}

$\mathrm{HC}$ was documented in 22 patients (37\%) at a median of 100 days after allo-HSCT (range: 0-367 days). The distribution of HC grades was as follows: 13/22 (59\%) grade 2, 2/22 (9\%) grade 3 , and $7 / 22(32 \%)$ grade 4 . Late-onset HC occurred in 18 patients (31\%). The median platelet count at the onset of $\mathrm{HC}$ was $52 \times 10^{9} / \mathrm{L}$ (range: $8-372 \times 10^{9} / \mathrm{L}$ ). Ten patients (17\%) developed $\mathrm{HC}$ before platelet and neutrophil engraftment. None of the patients had pro-hemorrhagic abnormality. Positive CMV reactivation was detected coincidently during $\mathrm{HC}$ episodes in 18 patients (31\%) at a median time of 72 days. In univariate analysis, myeloablative conditioning regimen, $\mathrm{Cy}$ administration, presence of acute GVHD, CMV reactivation, and $B K$ viremia were associated with a higher risk of $\mathrm{HC}(\mathrm{p}=0.022, \mathrm{p}=0.026, p=0.031$, $p=0.012$, and $p<0.0001$ respectively). In multivariate analysis, patients that received Cy (sub-distribution hazard ratio (sdHR): 7.82, Cl: 1.375-39.645, $p=0.020$ ) had CMV reactivation (sdHR: 6.105, Cl: 1.614-23.094, $p=0.008$ ), and were positive for BKV viremia (sdHR: $2.15, \mathrm{Cl}: 1.456-22.065, \mathrm{p}=0.01$ ) had significantly increased risk of developing $\mathrm{HC}$ (Table 2). HC occurred in 3 of 5 haploidentical allo-HSCT patients who received Cy at both conditioning and GVHD prophylaxis. Therefore, more detailed analysis of excess $\mathrm{Cy}$ was not possible.

BKV DNA assay positivity (copies $/ \mathrm{mL}>0$ ) in plasma was shown in at least one measurement in 30 patients (51\%). Eighteen of 59 patients (31\%) developed BKV-related HC during follow-up.
The frequency of plasma BKV positivity and the median number of viral copies $/ \mathrm{mL}$ at days $0,30,60$, and 90 are given in detail in Table 3. The numbers of patients that had $\mathrm{HC}$ at days $0,30,60$, and 90 were $4,16,14$, and 7 . The frequency of BKV positivity was increased in patients with late onset HC (day 0: 4/15 (26\%), day 30: 16/24 (66\%), day 60: 14/16 (87\%), day 90: 7/7 (100\%); $\mathrm{p}=0.007$ ).

We also investigated the predictive value of the BK viral load at day $0,30,60$, and 90 for the severity of hematuria. Patients with higher viral loads at days 30 and 60 were diagnosed with more severe hematuria $(p<0.001)$. The correlation between viral load and grade of hematuria grew stronger from day 0 to day 60 and then weaker from day 60 to day 90 (Table 4). According to ROC curve analysis, we suggest that median BK viral load of $>101.5$ copies $/ \mathrm{mL}$ at day 0 (sensitivity 0.727 , specificity 0.875 ), median BK viral load of $>98.5$ copies $/ \mathrm{mL}$ at day 30 (sensitivity 0.909 , specificity 0.875), and median BK viral load of $>90.0$ copies $/ \mathrm{mL}$ at day 60 (sensitivity 0.909 , specificity 0.875 ) are indicative of HC (Table 5).

Upon the occurrence of $\mathrm{HC}$, intravenous hydration was initiated for each patient. Nine of 22 patients ( $\mathrm{HC}$ of $\geq$ grade 3 ) had continuous bladder irrigation through a bladder catheter Platelet and RBC transfusions were administered to maintain platelets at $>50 \times 10^{9} / \mathrm{L}$ and hematocrit at $>25$. HC was resolved in 14 patients (64\%). Eight BKV-related HC patients received 0.5-1 $\mathrm{mg} / \mathrm{kg}$ intravenous cidofovir once every two weeks due to persistence of hematuria ( 7 patients had grade 4 hematuria and 1 patient had grade 3 hematuria) and increasing viral load. The median time to cidofovir treatment since the beginning of HC was 2 months (range: 1-3). Six of these 8 patients responded after a median of 2 doses (range: 1-5) of cidofovir treatment (75\%). Probenecid could not be administered because it was not available. None of the patients had renal compromise. Two unresponsive patients with grade 4 hematuria underwent mucous electrocoagulation and macroscopic hematuria disappeared. The median time from allo-HSCT to last followup was 14 months (range: 1-34). No statistically significant difference was detected in terms of survival in patients with or without HC.

\section{Discussion}

This prospectively designed study evaluates the risk factors for $\mathrm{HC}$ and illustrates the relationship between BK viremia and $\mathrm{HC}$ in allo-HSCT recipients. $\mathrm{HC}$ is a considerable cause of morbidity associated with prolonged hospitalization and urinary obstruction in severe cases after allo-HSCT [22]. HC was detected in 22 patients $(37 \%)$ at a median of 100 days after allo-HSCT (minimum-maximum: 0-367 days) in our study. The incidence of early $\mathrm{HC}$ in patients treated with normal doses of Cy who were adequately hydrated is $10 \%$ [23]. Despite the 


\begin{tabular}{|c|c|c|c|c|c|}
\hline Potential risk factor & HC-negative $(n, \%)$ & HC-positive $(n, \%)$ & $\begin{array}{l}\text { Univariate } \\
\text { p-value }\end{array}$ & $\begin{array}{l}\text { Multivariate SdHR (95\% } \\
\text { Cl) }\end{array}$ & $\begin{array}{l}\text { Multivariate } \\
\text { p-value }\end{array}$ \\
\hline Age $>50$ & $14(37.8 \%)$ & $4(18.2 \%)$ & 0.113 & & \\
\hline $\begin{array}{l}\text { Sex } \\
\text { Male } \\
\text { Female }\end{array}$ & $\begin{array}{l}22(37.3 \%) \\
15(25.4 \%)\end{array}$ & $\begin{array}{l}12(20.3 \%) \\
10(16.9 \%)\end{array}$ & 0.712 & & \\
\hline $\begin{array}{l}\text { Diagnosis } \\
\text { Benign (SAA, FAA) } \\
\text { Malignant (AML, ALL, MDS) }\end{array}$ & $\begin{array}{l}3(5.1 \%) \\
34(57.6 \%)\end{array}$ & $\begin{array}{l}4(6.8 \%) \\
18(30.5 \%)\end{array}$ & 0.407 & & \\
\hline $\begin{array}{l}\text { Stem cell source } \\
\text { Bone marrow } \\
\text { Peripheral blood }\end{array}$ & $\begin{array}{l}3(5.1 \%) \\
34(57.6 \%)\end{array}$ & $\begin{array}{l}4(6.8 \%) \\
18(30.5 \%)\end{array}$ & 0.407 & & \\
\hline $\begin{array}{l}\text { Donor type } \\
\text { Related } \\
\text { Unrelated }\end{array}$ & $\begin{array}{l}17(29 \%) \\
20(34 \%)\end{array}$ & $\begin{array}{l}11(19 \%) \\
11(19 \%)\end{array}$ & 0.793 & & \\
\hline $\begin{array}{l}\text { Conditioning regimen } \\
\text { Myeloablative } \\
\text { Reduced intensity }\end{array}$ & $\begin{array}{l}26(44.1 \%) \\
21(35.6 \%)\end{array}$ & $\begin{array}{l}11(18.6 \%) \\
1(1.7 \%)\end{array}$ & 0.022 & NE & \\
\hline Cy-containing regimen & $24(64.9 \%)$ & $20(90.9 \%)$ & 0.026 & SdHR: 7.82, Cl: 1.375-39.645 & $0.020^{*}$ \\
\hline Bu-containing regimen & $20(54 \%)$ & $10(45 \%)$ & 0.595 & & \\
\hline ATG-containing regimen & $20(54.1 \%)$ & $12(54.5 \%)$ & 0.971 & & \\
\hline Presence of acute GVHD & $20(54.1 \%)$ & $18(81.8 \%)$ & 0.031 & NE & \\
\hline $\begin{array}{l}\text { CMV reactivation } \\
\text { BK viremia }\end{array}$ & $\begin{array}{l}18(48.6 \%) \\
12(32.4 \%)\end{array}$ & $\begin{array}{l}18(81.8 \%) \\
18(81.8 \%)\end{array}$ & $\begin{array}{l}0.012 \\
<0.0001\end{array}$ & $\begin{array}{l}\text { SdHR: } 6.105 \\
\text { Cl: } 1.614-23.094 \\
\text { SdHR: } 2.15,0.011 \\
\text { Cl: } 1.456-22.065\end{array}$ & $0.008^{*}$ \\
\hline
\end{tabular}

\begin{tabular}{|c|c|}
\hline Day 0 & \\
\hline BK virus + patients, $n(\%)$ & $15(25 \%)$ \\
\hline Median number of BK viral copies/mL (range) & $10,949(23-614,608)$ \\
\hline Day 30 & \\
\hline BK virus + patients, n (\%) & $24(41 \%)$ \\
\hline Median number of BK viral copies/mL (range) & $2,604,813(10-37,869,641)$ \\
\hline Day 60 & \\
\hline BK virus + patients, $n(\%)$ & $16(27 \%)$ \\
\hline Median number of BK viral copies/mL (range) & $7,785(16-267,145)$ \\
\hline Day 90 & \\
\hline BK virus + patients, n (\%) & $7(12 \%)$ \\
\hline Median number of BK viral copies/mL (range) & $302,353(5-5,371,515)$ \\
\hline
\end{tabular}

Table 4. Correlation between grade of hematuria and BK viral load (copies/mL) (Spearman's rho). The correlation between viral load and grade of hematuria increased from day 0 to day 60 and then weakened between day 60 and day 90 .

\begin{tabular}{|l|l|l|l|l|} 
& \multicolumn{1}{|l|}{ Viral load at day $\mathbf{0}$} & Viral load at day 30* & Viral load at day 60* & Viral load at day 90 \\
& Spearman's rho $(r)-p$ & $0.855-<0.001$ & $0.576-0.064$ \\
\hline Grade of HC & $0.371-0.089$ & $0.787-<0.001$ & \\
\hline HC: Hemorrhagic cystitis.
\end{tabular}




\begin{tabular}{|c|c|c|c|c|c|}
\hline Variable & AUC & SE & $\begin{array}{l}95 \% \mathrm{C} \\
\mathrm{Min}\end{array}$ & Max & $\mathbf{p}$ \\
\hline Titer at day 0 & 0.813 & 0.101 & 0.615 & 1.000 & 0.023 \\
\hline Titer at day 30 & 0.858 & 0.099 & 0.663 & 1.000 & 0.009 \\
\hline Titer at day 60 & 0.881 & 0.089 & 0.707 & 1.000 & 0.006 \\
\hline Titer at day 90 & 0.744 & 0.114 & 0.520 & 0.968 & 0.076 \\
\hline
\end{tabular}

ability to decrease incidence through sufficient hydration and the use of mesna [24], conditioning-induced early-onset $\mathrm{HC}$ is still a problem and occurred in 7\% of our patients. We found increased risk for $\mathrm{HC}$ with myeloablative conditioning and the presence of acute GVHD in univariate analysis, and the use of Cy and the occurrence of CMV and BKV in multivariate analysis, similar to prior reports $[16,24,25,26]$.

The BK virus has been postulated to reactivate from a latent state in immunocompromised patients in the etiology of $\mathrm{HC}$ in allo-HCST recipients. The proposed pathogenesis of BKV-related HC occurs in three steps: 1) chemotherapy/irradiation damages the uroepithelium and decreases BKV-specific cellular immunity; 2) BKV replicates during the immunosuppressive phase; and 3) the immune attack further damages the uroepithelium after hematopoietic reconstitution [9]. To clarify the timing and severity of BKV-related $\mathrm{HC}$, plasma BK viral loads at days $0,30,60$, and 90 were included in our study. In agreement with the three-phase theory, we detected clinical BKV-related $\mathrm{HC}$ more frequently following engraftment. The correlation between the severity of $\mathrm{HC}$ and the plasma BK viral load was statistically significant at days 30 and 60. Some patients in our study had early-onset BKV-related HC, but it is essential to consider that the patients involved in the study were diagnosed mostly with malignant disease and received chemotherapy and immunosuppression prior to allo-HSCT. On the other hand, BKV DNA was also identified in healthy donor leukocytes and bone marrow cells [27]. In order to test the possibility of virus transmission during blood product transfusion or allo-HSCT, the BKV genotypes from both donors and patients were evaluated. Leung et al. demonstrated that patients with severe HC shared the donor BKV genotype, suggesting that transmission might be involved during transplantation [28]. Transmission or prior immunosuppression may explain our patients having early presentation of BKV-related HC prior to engraftment.

The incidence of BK viruria is about 50\% following allo-HSCT [5]. Patients with $\mathrm{HC}$ are prone to higher peak urine $\mathrm{BK}$ viral loads $[11,19,29]$. BK viruria of $>10^{7}$ copies $/ \mathrm{mL}$ is one of the diagnostic criteria for BK-related $\mathrm{HC}$ with a sensitivity of $86 \%$ and a specificity of $60 \%$ [20]. At the same time, in $40 \%-50 \%$ of HSCT patients with persistent viruria, HC did not develop $[2,29]$. Asymptomatic viral shedding in urine is found even in $5 \%$ of healthy individuals [30]. The positive predictive value of viremia is better than that of viruria for the occurrence of $\mathrm{HC}[1,31]$. The ECIL guidelines state that plasma BK virus loads of $>3-4 \log _{10}$ copies $/ \mathrm{mL}$ play a role in the management and follow-up of allo-HSCT recipients [20]. Viremia of $>10^{4}$ copies/mL for more than 3 weeks particularly contributes to $\mathrm{HC}$ in kidney transplant recipients [32]. Erard et al. [17] showed in a multivariate model that plasma viral load of more than $10^{4}$ copies/mL was associated with developing $\mathrm{HC}$ in allogeneic hematopoietic stem cell transplant recipients. Höller et al. [33] could not detect a predictive cutoff for plasma viral load in a recent study, but they indicated that the presence of viremia might itself predict BKV-associated morbidity. Interestingly, we detected a lower threshold $\left(2 \log _{10}\right)$ for BK-related HC in our prospective study, which might be related to the limited number of patients included in our study. We believe that closer followup should be considered for high-risk patients.

BK virus infection immune control depends on both CD4+ and CD8+ T-cells [34]. Although previous reports failed to demonstrate a correlation between GVHD and HC $[2,30,35]$, we found a positive correlation in a univariate model. The immunosuppression of GVHD and immunosuppressive treatment both contribute to mucosal damage and may cause uncontrolled proliferation of the BK virus. Similarly, CMV viremia causes impaired T-cell immunity and weak T-cell responses [36]. Interestingly, heterologous transcriptional transactivation of CMV by the BKV antigen was proposed to connect these two agents [37]. It is possible that the presence of GVHD or CMV viremia may contribute to $\mathrm{BK}$ virus-related $\mathrm{HC}$ at lower BKV thresholds in our study. Since BK virus infections are activations of latent viral infections rather than primary infections, BK virus $\mathrm{lgG}$ titers are a possible marker of latent infection [38].

The treatment of BKV-associated $\mathrm{HC}$ is still controversial. Cidofovir has been demonstrated to be active against BKV in vitro and in clinical studies [39,40,41,42]. Savona et al. [42] showed that $84 \%$ of patients clinically responded to cidofovir; however, only $47 \%$ had decreased viral load in the urine. The 
timing of application varies; the most widely accepted is to consider cidofovir in persistent hematuria for 2 weeks with a significant increase in viral load [6]. Eight patients received cidofovir in our study, in agreement with the literature. Leflunomide is an anti-CMV agent and may be effective in BK virus-infected patients [43]. Indeed, fluoroquinolones may be preferred as prophylactic agents against the BK virus with modest activity and a low selectivity index [44]. Tang et al. [45] demonstrated that surgical treatments, including embolization and mucous electrocoagulation, are safe and effective in severe refractory $\mathrm{HC}$. Recently, off-the-shelf virus-specific $\mathrm{T}$ cells were demonstrated to be a safe and effective broad-spectrum approach in severe viral infections after allo-HSCT [46]. BKV is a common cause of $\mathrm{HC}$ in $\mathrm{HSCT}$, and it is associated with increased hospital costs due to prolonged hospitalization, a 2- to 3-fold increase in RBC and platelet transfusions, and cidofovir treatment if needed [47].

\section{Conclusion}

$\mathrm{HC}$ is a common complication of allo-HSCT that remains a challenge. Our prospective data confirmed that administration of $\mathrm{Cy}$, myeloablative conditioning, the presence of GVHD, CMV reactivation, and $\mathrm{BKV}$ infection are risk factors for $\mathrm{HC}$ in alloHSCT recipients. The sensitivity and specificity of the plasma BK PCR test was increased in later periods after transplant for diagnosis of BKV-related HC. Routine plasma BK viral monitoring at days 0,30 , and 60 after transplant may assist in the diagnosis and treatment of BKV-related $\mathrm{HC}$.

\section{Acknowledgment}

This project was approved by the institutional ethical board on 24 November 2014 and was supported by the Scientific Projects Department, Grant Number 15B0230007.

\section{Ethics}

Ethics Committee Approval: Institutional ethical board approval and the informed consent of all participants were obtained. This project was supported by grant number 15B0230007.

Informed Consent: Obtained.

\section{Authorship Contributions}

Concept: E.A.; Design: E.A.; Data Collection or Processing: E.A., A.U., P.A.A., I.D., A.T.; Analysis or Interpretation: E.A., C.A., P.A.A., A.T., P.T.; Literature Search: E.A.; Writing: E.A.

Conflict of Interest: No conflict of interest was declared by the authors.

Financial Disclosure: The authors declared that this study received no financial support.

\section{References}

1. Hirsch HH, Steiger J. Polyomavirus BK. Lancet Infect Dis 2003;3:611-623.

2. Bedi A, Miller CB, Hanson JL, Goodman S, Ambinder RF, Charache P, Arthur $R R$, Jones RJ. Association of BK virus with failure of prophylaxis against hemorrhagic cystitis following bone marrow transplantation. J Clin Oncol 1995;13:1103-1109.

3. Shepherd JD, Pringle LE, Barnett MJ, Klingemann HG, Reece DE, Phillips GL. Mesna versus hyperhydration for the prevention of cyclophosphamideinduced hemorrhagic cystitis in bone marrow transplantation. J Clin Oncol 1991;9:2016-2020.

4. Tomonari A, Takahashi S, Ooi J, Fukuno K, Takasugi K, Tsukada N, Konuma T, Ohno N, Uchimaru K, Iseki T, Tojo A, Asano S. Hemorrhagic cystitis in adults after unrelated cord blood transplantation: a single institution experience in Japan. Int J Hematol 2006;84:268-271.

5. Seber A, Shu XO, Defor T, Sencer S, Ramsay N. Risk factors for severe hemorrhagic cystitis following BMT. Bone Marrow Transplant 1999;23:3540.

6. Dropulic LK, Jones RJ. Polyomavirus BK infection in blood and marrow transplant recipients. Bone Marrow Transplant 2008;41:11-18.

7. Decker DB, Karam JA, Wilcox DT. Pediatric hemorrhagic cystitis. J Pediatr Urol 2009;5:254-264.

8. Apperley JF, Rice SJ, Bishop JA, Chia YC, Krausz T, Gardner SD, Goldman JM. Late-onset hemorrhagic cystitis associated with urinary excretion of polyomaviruses after bone marrow transplantation. Transplantation 1987;43:108-112.

9. Leung AYH, Yuen KY, Kwong YL. Polyoma BK virus and haemorrhagic cystitis in haematopoietic stem cell transplantation: a changing paradigm. Bone Marrow Transplant 2005;36:929-937.

10. Giraud G, Bogdanovic G, Priftakis P, Remberger M, Svahn BM, Barkholt L, Ringden 0 , Winiarski J, Ljungman P, Dalianis T. The incidence of hemorrhagic cystitis and BK-viruria in allogeneic hematopoietic stem cell recipients according to intensity of the conditioning regimen. Haematologica 2006;91:401-404.

11. Bogdanovic $G$, Priftakis $P$, Giraud G, Kuzniar M, Ferraldeschi R, Kokhaei $P$,

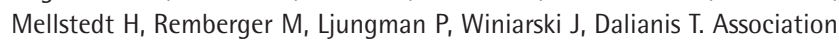
between a high BK virus load in urine samples of patients with graft-versushost disease and development of hemorrhagic cystitis after hematopoietic stem cell transplantation. J Clin Microbiol 2004;42:5394-5396.

12. Kitumura $T$, Aso $Y$, Kuniyoshi $N$, Hara $K$, Yogo $Y$. High incidence of urinary $J C$ virus excretion in nonimmunosuppressed older patients. J Infect Dis 1990;161:1128-1133.

13. Behzad-Behbahani A, Klapper PE, Vallely PJ, Cleator GM, Khoo SH. Detection of $B K$ virus and JC virus DNA in urine samples in immunocompromised (HIV-infected) and immunocompetent (HIV-non-infected) patients using polymerase chain reaction and microplate hybridization. J Clin Virol 2004;29:224-229.

14. Arthur RR, Shah KV, Baust SJ, Santos GW, Saral R. Association of BK viruria with hemorrhagic cystitis in recipients of bone marrow transplants. N Engl J Med 1986;315:230-234.

15. Arthur RR, Shah KV, Charache $P$, Saral R. BK and JC virus infections in recipients of bone marrow transplants. J Infect Dis 1988;158:563-569.

16. Rorije NM, Shea MM, Satyanarayana G, Hammond SP, Ho VT, Baden LR, Antin JH, Soiffer RJ, Marty FM. BK virus disease after allogeneic stem cell transplantation: a cohort analysis. Biol Blood Marrow Transplant 2014;20:564-570.

17. Erard V, Kim HW, Corey L, Limaye A, Huang ML, Myerson D, Davis C, Boeckh M. BK DNA viral load in plasma: evidence for an association with hemorrhagic cystitis in allogeneic hematopoietic cell transplant recipients. Blood 2005;106:1130-1132. 
18. Cesaro $S$, Facchin C, Tridello G, Messina C, Calore E, Biasolo MA, Pillon M, Varotto S, Brugiolo A, Mengoli C, Palu G. A prospective study of BKvirus associated haemorrhagic cystitis in paediatric patients undergoing allogeneic haematopoietic stem cell transplantation. Bone Marrow Transplant 2008;41:363-370.

19. Wong AS, Chan KH, Cheng VCC, Yuen KY, Kwong YL, Leung AYH. Relationship of pretransplantation polyoma BK virus serologic findings and BK viral reactivation after hematopoietic stem cell transplantation. Clin Infect Dis 2007;44:830-837.

20. Cesaro $S$, Dalianis $T$, Hanssen Rinaldo $C$, Koskenvuo M, Pegoraro A, Einsele $H_{\text {, }}$ Cordonnier C, Hirsch HH; ECIL-6 Group. ECIL guidelines for the prevention, diagnosis and treatment of BK polyomavirus-associated haemorrhagic cystitis in haematopoietic stem cell transplant recipients. J Antimicrob Chemother 2018;73:12-21.

21. Silva $L$ de $P$, Patah $P A$, Saliba RM, Szewczyk NA, Gilman $L$, Neumann J, Han XY, Tarrand J, Ribeiro R, Gulbis A, Shpall EJ, Jones R, Popat U, Walker JA, Petropoulos D, Chiattone A, Stewart J, El-Zimaity M, Anderlini P, Giralt S, Champlin RE, de Lima M. Hemorrhagic cystitis after allogeneic hematopoietic stem cell transplants is the complex result of BK virus infection, preparative regimen intensity and donor type. Haematologica 2010;95:1183-1190.

22. Gaziev J, Paba $P$, Miano R, Germani $S$, Sodani $P$, Bove $P$, Perno CF, Marziali $M$, Gallucci $C$, Isgrò $A$, Paciaroni $K$, Roveda A, Simone MD, De Angelis $G$, Alfieri C, Lucarelli G. Late-onset hemorrhagic cystitis in children after hematopoietic stem cell transplantation for thalassemia and sickle cell anemia: a prospective evaluation of polyoma (BK) virus infection and treatment with cidofovir. Biol Blood Marrow Transplant 2010;16:662-671.

23. Pratt W, Ruddon R, Ensminger W MJ. The Anticancer Drugs. New York, Oxford University Press, 1994.

24. Atilla PA, Atilla E, Toprak SK, Demirer T. Non-infectious early complications of allogeneic stem cell transplantations. UHOD 2016;26:239-250.

25. Giraud G, Priftakis P, Bogdanovic G, Remberger $M$, Dubrulle $M$, Hau A, Gutmark R, Mattson J, Swahn BM, Ringden 0, Winiarski J, Ljungman $\mathrm{P}$, Dalianis T. BK-viruria and haemorrhagic cystitis are more frequent in allogeneic haematopoietic stem cell transplant patients receiving full conditioning and unrelated-HLA-mismatched grafts. Bone Marrow Transplant 2008;41:737-742.

26. Dosin G, Aoun F, Rassy EE, Assi T, Lewalle P, Blanc J, Van Velthoven R, Bron D. Viral-induced hemorrhagic cystitis after allogeneic hematopoietic stem cell transplant. Clin Lymphoma Myeloma Leuk 2017;17:438-442.

27. Dolei A, Pietropaolo V, Gomes E, Di Taranto C, Ziccheddu M, Spanu MA, Lavorino C, Manca M, Degener AM. Polyomavirus persistence in lymphocytes: prevalence in lymphocytes from blood donors and healthy personnel of a blood transfusion centre. J Gen Virol 2000;81:1967-1973.

28. Leung $A Y H$, Chan $M$, Kwong YL. Genotyping of the non-coding control region of BK virus in patients with haemorrhagic cystitis after allogeneic haematopoietic stem cell transplantation. Bone Marrow Transplant 2005;35:531-532.

29. Leung AY, Suen CK, Lie AK, Liang RH, Yuen KY, Kwong YL. Quantification of polyoma BK viruria in hemorrhagic cystitis complicating bone marrow transplantation. Blood 2001;98:1971-1978.

30. Egli A, Infanti L, Dumoulin A, Buser A, Samaridis J, Stebler C, Gosert R, Hirsch $\mathrm{HH}$. Prevalence of polyomavirus BK and JC infection and replication in 400 healthy blood donors. J Infect Dis 2009;199:837-846.

31. Vilchez RA, Kusne S. Molecular and clinical perspectives of polyomaviruses: emerging evidence of importance in non-kidney transplant populations. Liver Transpl 2006;12:1457-1463.

32. Drachenberg CB, Papadimitriou JC. Polyomavirus-associated nephropathy: update in diagnosis. Transpl Infect Dis 2006;8:68-75.

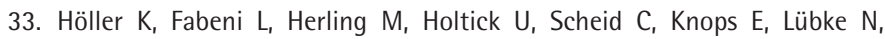
Kaiser R, Pfister $H$, Di Cristanziano V. Dynamics of BKPyV reactivation and risk of hemorrhagic cystitis after allogeneic hematopoietic stem cell transplantation. Eur J Haematol 2017;99:133-140.

34. Renner FC, Dietrich H, Bulut N, Celik D, Freitag E, Gaertner N, Karoui S, Mark J, Raatz C, Weimer R, Feustel A. The risk of polyomavirus-associated graft nephropathy is increased by a combined suppression of CD8 and CD4 celldependent immune effects. Transplant Proc 2013;45:1608-1610.

35. Kloos RQH, Boelens JJ, de Jong TPVM, Versluys B, Bierings M. Hemorrhagic cystitis in a cohort of pediatric transplantations: incidence, treatment, outcome, and risk factors. Biol Blood Marrow Transplant 2013;19:12631236.

36. Bennett SM, Broekema NM, Imperiale MJ. BK polyomavirus: emerging pathogen. Microbes Infect 2012;14:672-683.

37. Kristoffersen AK, Johnsen Jl, Seternes OM, Rollag $H$, Degre $M$, Traavik T. The human polyomavirus BK T antigen induces gene expression in human cytomegalovirus. Virus Res 1997;52:61-71.

38. Koskenvuo M, Dumoulin A, Lautenschlager I, Auvinen E, Mannonen L, Anttila VJ, Jahnukainen K, Saarinen-Pihkala UM, Hirsh HH. BK polyomavirus associated hemorrhagic cystitis among pediatric allogeneic bone marrow transplant recipients: treatment response and evidence for nosocomial transmission. J Clin Virol 2013;56:77-81.

39. Ahsan N, Shah KV. Polyomaviruses and Human Diseases. New York, Springer, 2006.

40. De Clercq E, Holy A. Acyclic nucleoside phosphonates: a key class of antiviral drugs. Nat Rev Drug Discov 2005;4:928-940.

41. Held TK, Biel SS, Nitsche A, Kurth A, Chen S, Gelderblom HR, Siegert W. Treatment of BK virus-associated hemorrhagic cystitis and simultaneous CMV reactivation with cidofovir. Bone Marrow Transplant 2000;26:347350.

42. Savona MR, Newton D, Frame D, Levine JE, Mineishi S, Kaul DR. Lowdose cidofovir treatment of BK virus-associated hemorrhagic cystitis in recipients of hematopoietic stem cell transplant. Bone Marrow Transplant 2007;39:783-787.

43. Ehlert K, Groll AH, Kuehn J, Vormoor J. Treatment of refractory CMVinfection following hematopoietic stem cell transplantation with the combination of foscarnet and leflunomide. Klin Padiatr 2006;218:180-184

44. Randhawa PS. Anti-BK virus activity of ciprofloxacin and related antibiotics. Clin Infect Dis 2005;4:1366-1367.

45. Tang FF, Zhang $X H$, Chen $H$, Chen $Y Y$, Han W, Wang JZ, Wang FR, Chen $Y$, Huang XJ, Xu LP. Surgical treatment of severe, refractory hemorrhagic cystitis following allogeneic hematopoietic stem cell transplantation: a report of 17 patients. Zhonghua Nei Ke Za Zhi 2017;56:414-418.

46. Tzannou I, Papadopoulou A, Naik S, Leung K, Martinez CA, Ramos CA, Carrum G, Sasa G, Lulla P, Watanabe A, Kuvalekar M, Gee AP, Wu MF, Liu $\mathrm{H}$, Grilley BJ, Krance RA, Gottschalk S, Brenner MK, Rooney CM, Heslop $\mathrm{HE}$, Leen AM, Omer B. Off-the-shelf virus-specific T cells to treat Bk virus, human herpesvirus 6, cytomegalovirus, Epstein-Barr virus, and adenovirus infections after allogeneic hematopoietic stem-cell transplantation. J Clin Oncol 2017;35:3547-3557.

47. Gilis L, Morisset $S$, Billaud G, Ducastelle-Leprêtre $S$, Labussière-Wallet $H$ Nicolini FE, Barraco F, Detrait M, Thomas X, Tedone N, Sobh M, Chidiac C, Ferry T, Salles G, Michallet M, Ader F; Lyon BK virus Study group. High burden of BK virus-associated hemorrhagic cystitis in patients undergoing allogeneic hematopoietic stem cell transplantation. Bone Marrow Transplant 2014;49:664-670. 